\title{
"The association between Corporate Social Responsibility Disclosure and accounting-based financial performance: a Kuwaiti evidence"
}

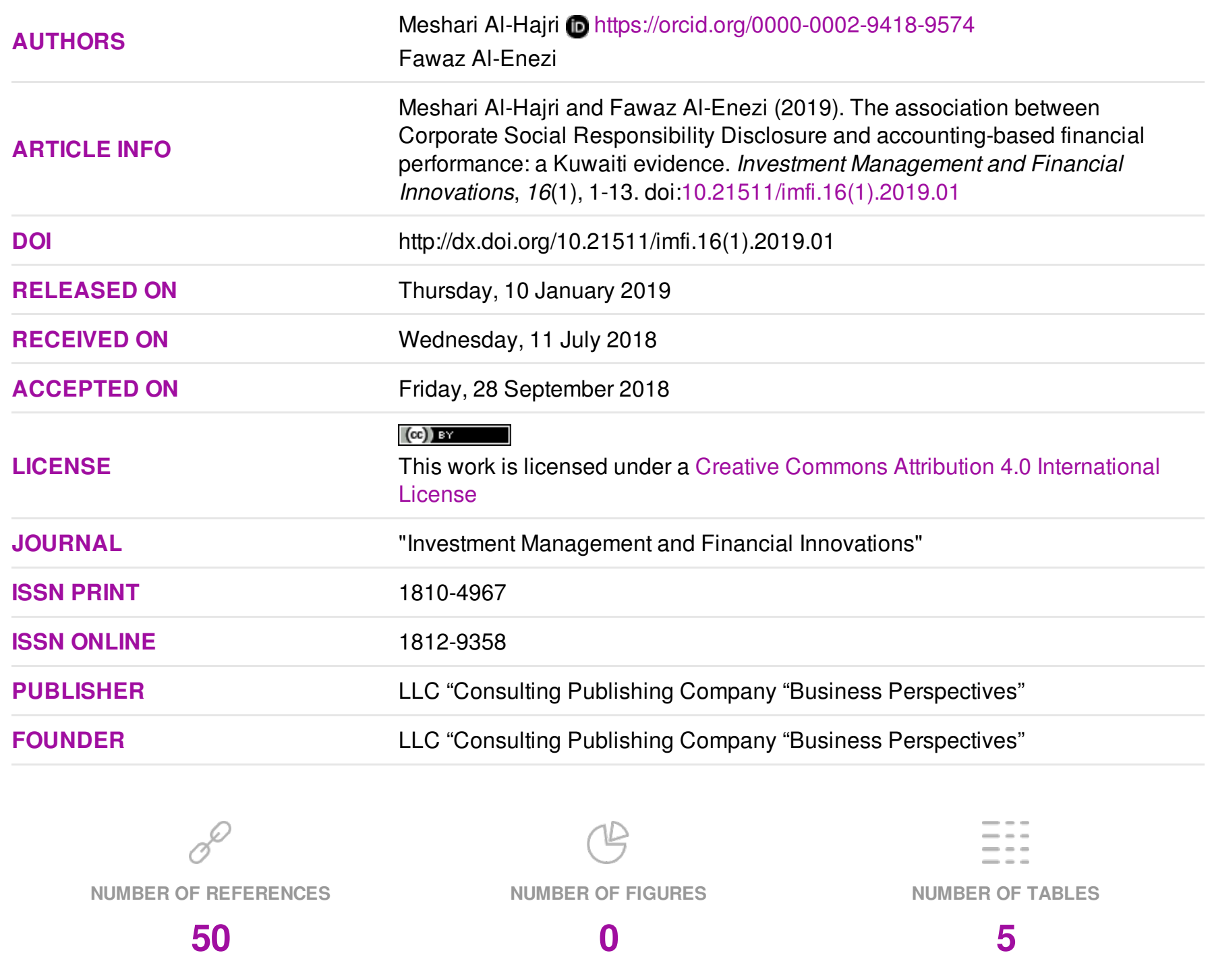

(C) The author(s) 2023. This publication is an open access article. 


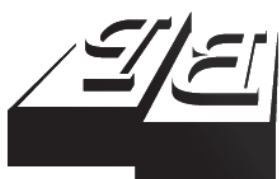

BUSINESS PERSPECTIVES

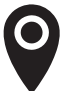

LLC "CPC "Business Perspectives" Hryhorii Skovoroda lane, 10, Sumy, 40022, Ukraine

www.businessperspectives.org

Received on: $11^{\text {th }}$ of July, 2018 Accepted on: $28^{\text {th }}$ of September, 2018

(C) Meshari Al-Hajri, Fawaz Al-Enezi, 2019

Meshari Al-Hajri, Ph.D., Department of Accounting, College of Business Administration, Kuwait University, Kuwait.

Fawaz Al-Enezi, Ph.D., Department of Sociology, College of Social Sciences, Kuwait University, Kuwait.

\section{() (i)}

This is an Open Access article, distributed under the terms of the Creative Commons Attribution 4.0 International license, which permits unrestricted re-use, distribution, and reproduction in any medium provided the original work is properly cited.

\section{THE ASSOCIATION BETWEEN CORPORATE SOCIAL RESPONSIBILITY DISCLOSURE AND ACCOUNTING-BASED FINANCIAL PERFORMANCE: A KUWAITI EVIDENCE}

\begin{abstract}
The current study aims at extending prior accounting research on the association between Corporate Social Responsibility Disclosure (CSRD) and Corporate Financial Performance (CFP) using a sample of listed firms on Kuwait Stock Exchange (KSE) from 2011 to 2012. It conducts a regression analysis to investigate the association between CSRD and CFP, as well as investigates the impact of firm size, leverage, and industry affiliation as the key determinants suggested by prior research on the level of CSRD. The results of the present study reveal that both CFP and firm size have significant positive associations with CSRD, whereas, in contrast, firm's leverage and firm's industry affiliation show non-significant associations with CSRD.
\end{abstract}

Keywords

Corporate Social Responsibility, accounting measures, Corporate Financial Performance, Kuwait

JEL Classification M40

\section{INTRODUCTION}

For the last 20 years, Corporate Social Responsibility Disclosure (CSRD) has attracted a growing admiration and respect among academics, as well as professionals (e.g. Chang et al., 2017). Elias and Epstein (1975, p. 36) pointed out that "CSRD involves the reporting of aspects related to the way a business entity is involved in social activities Similarly, Gray et al. (1996) defined it as a communication process that firms use to communicate the social impacts of their economic actions to specific groups within their society. It shows how business entities as members of the society address both social and environmental issues of concern to the surrounding communities in their operations and activities (Kok et al., 2001). The association between CSRD and Corporate Financial Performance (CFP) was an issue that has drawn the attention of several accounting researchers (e.g., Muttakin et al., 2015; Chang et al., 2017; Bani-Khalid et al., 2017). Investigating the CSRD-CFP association has been an appealing research issue, as obtaining an understanding about this association is expected to be instrumental for the corporate management, as well as the different groups of the firm's stakeholders (Simpson \& Kohers, 2002). In a review of prior CSRD-CFP, Gray (2006) suggested that empirical findings reported about this association are mixed, leaving only indecisive conclusions about this research issue. In addition, prior related research suggests that investigating the CSRD-CFP association is knotty both theoretically and methodologically (e.g. Carroll, 2000). Hence, further investigation of this association is apparently needed. 
The objective of the current study is to answer two main research questions. First, whether there is a significant association between CSRD and CFP for a sample of Kuwaiti listed companies. Second, whether CSRD in Kuwait is affected by the same key drivers documented in prior CSRD research. As indicated earlier, the research questions of interest in the current paper may have been examined considerably in prior research and across different countries. Empirical results reported about these questions, however, are still not conclusive (Bani-Khalid et al., 2017). In addition, much of previous empirical research examining factors influencing CSRD has been conducted in the context of Western or East-Asian countries' markets, with very few studies carried out to examine such issues in the context of other parts of the world. Furthermore, no research, the authors are aware of, has empirically investigated the CSRDCFP relation in the context of the emerging Kuwaiti market. The current study, therefore, intends to expand this line of accounting research by providing empirical evidence about this relation from a setting that has not been explored previously, where corporate governance regulations has been almost absent, and where corporate ownership structure in listed firms is featured by high concentration (AlFraih et al., 2012). In particular, this study attempts to contribute in filling the extant shortage in the international literature by providing further empirical evidence about (i) whether there is an association between CSRD and CFP in the context of the Kuwaiti market, and (ii) whether CSRD in Kuwait is ine fluenced by some key CSRD determinants, namely firm size, leverage, and industry affiliation. The current study, therefore, contributes to the international literature by reporting empirical evidence about these research questions in the context of an unexplored emerging market. The results reported in the current study reveal that CSRD in Kuwait is significantly associated with CFP as well as firm size. The results reported, nonetheless, financial leverage nor industry affiliation have any significant associations with CSRD. The findings offered by this study are anticipated to be interest to accounting and business researchers, and to be of practical implications for corporate management, investors and different interested parties. The structure of the paper proceeds as follows. Firstly, section 1 presents an overview on the study's theoretical framework. Section 2 reviews the related literature. Secondly, section 3 offers some details on the research method. Section 5 shows the empirical analysis of the current study. Finally, last section reports the study's conclusions.

\section{THEORY AND BACKGROUND}

\subsection{Theoretical framework of the study}

CSRD practices have been studied in light of a number of theoretical perspectives such as stakeholder theory, agency theory, legitimacy theory and institutional theory. However, stakeholder and legitimacy theories often have been used to explain why business entities engage in CSRD.

\subsubsection{Stakeholder theory}

Solomon (2010) posits that "stakeholder theory could be regarded as a conceptual mixture from different disciplines that renders interesting sociological and organizational interpretations for corporate behaviors. Stakeholder theory gives a great deal of attention to the company's stake- holders and argues that a company should give special attention to meet their interests and needs (Maignan \& Ferrell, 2004). From the perspective of stakeholder theory, not only corporate shareholders are affected by firm's activities, but also other different groups (Freeman, 1999). The stakeholder perspective argues that besides shareholders, other constituencies are influenced by firm's activities (Freeman, 1999). The basic idea here is that the success of the company and its continuation in its activities depends mainly on how the company manages its relations with these different groups of stakeholders (Freeman \& Philips, 2002).

\subsubsection{Legitimacy theory}

In line with stakeholder theory, legitimacy theory argues that firms' survival depends significantly on their adherence to the boundaries of what the society considers socially acceptable behaviors" (Mousa, 2010). Consequently, a company needs to confirm its legitimacy by maintaining a good re- 
lationship with its stakeholders to keep their endorsement and support for a company's goals and activities (Elsbach \& Sutton, 1992). It is argued that stakeholders who possess greater influence and perseverance will know more about organization's CSR initiatives than other less influential stakeholders (Peloza \& Papania, 2008). Legitimacy theory gives a corporate management the chance to handle CSRD to sway and distort the company's reports in a manner, which is favorable to the company (Kokubu et al., 1994). It can be argued that both legitimacy and stakeholder theories are complementary to each other, as they provide an answer to the fundamental question of why firms provide CSRD. While legitimacy theory argues that firms are engaging in CSRD to maintain their legitimacy and to continue their activities in society through obtaining the acceptance of stakeholders, the other theory, stakeholder theory, points out that firms are involving in CSRD to meet the interests and needs of stakeholders.

\subsection{The Kuwaiti stock market}

The Kuwaiti stock market is indeed one of the oldest equity markets in the Arab world. The enormous upsurge in the Kuwaiti economy following the production of oil in the mid of the 20th century has resulted in a huge increase in commerce and business activities in Kuwaiti. This escalation of the volume of business was accompanied by a dramatic upsurge in the number of companies operating in the market, and has resulted in a need for a market where investors can raise and exchange equity. Although equity trading was practiced in Kuwait as early as the 1950's, it was not until the 1970's that it was officially organized. In 1982, the Kuwaiti stock market witnessed a huge market crash, known as 'Al-Manakh crisis', due to the insufficient and lacking supervision that was in place at that time. Soon after the crash, the Kuwait Stock Exchange (KSE) was established in 1983 to oversee equity trading in the Kuwaiti market. Although KSE establishment led to some improvements in governing equity trading activities, supervision and monitoring over these activities remained substandard until 2010 when the Capital Markets Authority (CMA) was established. CMA is currently the chief governing body for regulating and overseeing activities related to equity trading in the Kuwaiti capital market.
In terms of market capitalization, the Kuwaiti stock market is among the largest markets in the Arab world. Over the last two years, market capitalization of Kuwaiti stock market has increased from around $\$ 87$ billion in 2016 to about $\$ 93$ billion in 2017. As of June 2018, the number of firms listed on the Kuwaiti stock market totaled 175 firms divided into 12 different market sectors.

\section{LITERATURE REVIEW AND THE HYPOTHESES DEVELOPMENT}

\subsection{CSRD and CFP}

Literature on the association between CSRD and CFP has offered different approaches with different theoretical foundations. However, mixed and conflicting results are reported. Table 1 shows some of these studies.

A number of studies suggested a positive association between CSRD and CFP with different explanations. For example, proponents of the "social impact hypothesis" of the stakeholders theory (e.g. Alturki, 2014) suggest that when a firm commits itself to meeting the needs of non-owner stakeholders (e.g. customers, employees, etc.), this will lead to enhancing its image and reputation in the society, which will consequently be reflected in its financial performance. This notion is backed by empirical evidence that firm's devotion to (and disclosure of) socially responsible activities and actions leads to lowering its cost of capital, and, in turn, leads to improving its financial results, and vice versa (Dhaliwal et al., 2011). This way, CSRD can be seen as a channel that companies use to communicate their dedication to meeting stakeholders' expectations and demands. Another possible reason suggested for the positive association between CSRD and CFP is that companies that commit themselves to socially responsible behaviors are in general companies with capable management, and hence are expected to perform well financially as well. In fact, the CSRD literature includes research (e.g. Bowman \& Haire, 1976; Belkaoui \& Karpik, 1989), suggesting that firms with high levels of CSRD generally possess the skills needed to run their operations profitably. An 
Table 1. List of some previous CSRD and CFP studies

\begin{tabular}{|c|c|c|c|}
\hline The author(s) & Sample and country & Main objective & Main results \\
\hline $\begin{array}{l}\text { Chang et al. } \\
(2017)\end{array}$ & $\begin{array}{l}\text { Listed firms on Shanghai Stock } \\
\text { Exchange (SSE) from } 2009 \text { to } 2013\end{array}$ & $\begin{array}{l}\text { To examine the effect of CSRD } \\
\text { on CFP }\end{array}$ & $\begin{array}{l}\text { Profitability is the most important } \\
\text { variable associated with CSRD, } \\
\text { while firm age and corporate } \\
\text { governance (CG) have little effect } \\
\text { on CSRD }\end{array}$ \\
\hline $\begin{array}{l}\text { Bani-Khalid et al. } \\
\text { (2017) }\end{array}$ & $\begin{array}{l}66 \text { listed firms in Jordan (from } 2010 \text { to } \\
\text { 2012) }\end{array}$ & $\begin{array}{l}\text { To examine how corporate } \\
\text { characteristics could influence } \\
\text { the CSRD }\end{array}$ & $\begin{array}{l}\text { Financial performance and firm } \\
\text { size are significantly associated } \\
\text { with CSRD, however, age, type } \\
\text { of industry, profitability, and } \\
\text { ownership are not related to } \\
\text { CSRD }\end{array}$ \\
\hline $\begin{array}{l}\text { Muttakin et al. } \\
(2015)\end{array}$ & $\begin{array}{l}116 \text { listed Bangladeshi non-financial } \\
\text { firms (from } 2005 \text { to 2009) }\end{array}$ & $\begin{array}{l}\text { To investigate the relationship } \\
\text { between CSR disclosure and a } \\
\text { number of factors, namely firm } \\
\text { size, profitability and board } \\
\text { diversity }\end{array}$ & $\begin{array}{l}\text { Firm size and profitability are the } \\
\text { most determinining variable of } \\
\text { CSR, while other variables have a } \\
\text { negative effect on CSRD }\end{array}$ \\
\hline Alturki (2014) & $\begin{array}{l}116 \text { non-financial listed firms during } \\
\text { the period 2012-2013 in Saudi Arabia }\end{array}$ & $\begin{array}{l}\text { To examine the determinants of } \\
\text { CSRD Saudi firms }\end{array}$ & $\begin{array}{l}\text { There is a significant and positive } \\
\text { relation between company's } \\
\text { CSRD and its profitability, size, } \\
\text { and age, while leverage has a } \\
\text { non-significant association with } \\
\text { CSRD }\end{array}$ \\
\hline $\begin{array}{l}\text { Giannarakis et al. } \\
(2014)\end{array}$ & 100 US listed firms (from 2009 to 2012) & $\begin{array}{l}\text { To investigate the vital } \\
\text { determinants of CSRD }\end{array}$ & $\begin{array}{l}\text { Firm's industrial profile seems } \\
\text { to have a significant impact on } \\
\text { CSRD }\end{array}$ \\
\hline $\begin{array}{l}\text { Macarulla and } \\
\text { Talalweh (2012) }\end{array}$ & 132 Saudi Arabian listed firms in 2008 & $\begin{array}{l}\text { To examine the determinants of } \\
\text { CSRD in Saudi firms focusing on } \\
\text { firm characteristics }\end{array}$ & $\begin{array}{l}\text { Firm size, profitability and type } \\
\text { of industry are the main variables } \\
\text { associated with CSRD }\end{array}$ \\
\hline
\end{tabular}

additional explanation suggested for the CSRDCFP positive association is that companies that devote some of their resources for CSRD activities are generally companies with superb CFP (Preston \& O'Bannon, 1997). Moreover, some authors (e.g. Milne, 2002) suggested that the positive association between CSRD and CFP is because firms with large profits generally have a greater incentive to disclose their CSRD activities in an effort to divert general public attention and to avoid any potential political intervention away from their profits.

On the other hand, researchers who suggested an inverse association between the level of CSRD and CFP basically argue that a high level of CSRD means more amounts of firm's economic resources spent on CSRD activities, and hence lower amounts of profit (Salzmann et al., 2005). Moreover, research suggesting a negative relation between CSRD and CFP includes also studies (e.g. Preston \& O’Bannon, 1997) that proposed the "managerial opportunistic behavior" hypothesis and suggested that corporate management interested mainly in serving its own interest is expected to reduce expenditures on (and disclosure of) CSRD activities when the firm is doing well financially in order to maximize firm's reported profits and hence executive compensation. This hypothesis continues to suggest that when the firm is financially experiencing a bad time, firm's management tend to "opportunistically" increase CSRD in order to divert public attention from its bad performance.

Based on previous discussion, the association between CSRD and CFP has reported mixed results. Several studies report a significant positive association between the level of CSRD and CFP (e.g., Simpson \& Kohers, 2002; Khan et al., 2013). Other studies (Aras et al., 2010), however, could not report any significant association between CSRD and CFP. Although empirical results reported in previous research about the CSRD-CFP association are mixed, these research findings are mostly suggestive of a positive association between the CSRD level and CFP. Therefore, the study's first hypothesis is specified as follows:

H1: There is a significant positive relation between the amount of CSRD and CFP.

\subsection{The key determinates of the amount of CSRD}

\subsubsection{Firm size}

The CSRD literature includes a number of theoretical bases offered to explain the effect of firm size on its CSRD. Since larger firms are more visible to social activists groups, they are expected to 
disclose more CSRD as a public relations mechanism used to contain the possible offences of social activists groups (Belkaoui \& Karpik, 1989). Other authors suggested different reasons for the positive relation between the amount of CSRD and firm size. For example, Bujaki and Richardson (1997) suggested that larger firms are expected to provide more CSRD, since the cost of supplemental information disclosure is lower in these firms, as they typically enjoy more advanced reporting systems, which makes it more "economical" for large firms to provide CSRD compared to smaller firms. Other authors (e.g., Singhvi \& Desai, 1971) suggested that another possible reason for expecting a positive association between the CSRD level and firm size is that smaller firms, due to their competitive disadvantage, are expected to be more disinclined to disclose any kind of extra information (e.g. CSRD).

The relation between CSRD and firm size has been examined empirically in most of previous CSRD research. As indicated earlier, the common idea is that larger firms are expected to disclose more CSRD as a result of the greater pressures they face by the public to report information about their CSRD activities (Cowen et al., 1987). Empirical findings of previous related studies in general suggested a positive association between the amount of firm's CSRD and firm size (Muttakin \& Khan, 2014; Muttakin et al., 2015; Bani-Khalid et al., 2017). In light of prior research, larger firms are expected to provide more CSRD than smaller firms, and the second hypothesis of the present study, therefore, is:

H2: There is a significant positive relation between firm size and the amount of CSRD.

\subsubsection{Leverage}

Several previous CSRD studies (Wallace et al., 1994; Khlif \& Souissi, 2010) showed that firm's leverage is significant in explaining the amount of CSRD by firms. Empirically, however, the directional impact of this variable on the CSRD is still unclear. On the one hand, some studies (e.g., Haniffa \& Cooke, 2005) suggested that high leveraged firms have a greater incentive to provide more CSRD, as they need to legitimize their actions. Other studies (e.g., Purushothaman et al.,
2000), however, suggested that firms with high leverage are expected to have very close ties with their creditors, and, therefore, are expected to have other channels for disclosing to them their CSRD activities and actions. In view of the aforementioned opposite arguments and mixed empirical results, no prediction is made about the direction of the relation between the amount of CSRD and firm's leverage. The current study's third hypothesis, therefore, is as follows:

\section{H3: There is a significant association between firm's leverage and the amount of CSRD.}

\subsubsection{Industry affiliation}

The voluntary disclosure line of research in the accounting literature includes studies (e.g., Dye and Sridhar, 1995) showing that the amount of firms' voluntary disclosure is considerably affected by the characteristics of the industry they belong to. Prior CSRD research (e.g., Cormier et al., 2005) suggested that firms' decision with regard to the amount of CSRD is significantly influenced by their industries' characteristics. Moreover, empirical results documented in previous CSRD research (e.g., Kotonen, 2009) reveal a significant association between the amount of firm's CSRD and its industry affiliation. For example, some studies (e.g., Reverte et al., 2009) found that firms that belong to "environment sensitivity" industries tend to make considerably high amounts of CSRD than other firms. Industries with high environment sensitivity are industries with manufacturing operations that potentially have harmful impacts on the environment. In general, these industries include, for example, oil, mining and chemical industries. Prior related research (Clarke \& Gibson-Sweet, 1999) showed that firms belonging to these industries tend to provide more CSRD about environment, health, and safety. Empirical evidence was documented in previous research, therefore, the amount of CSRD is expected to depend greatly on the environment sensitivity of their industry. The current study's forth hypothesis, therefore, is specified as follows:

H4: There is a significant positive association between the company's industry affiliation and the amount of CSRD. 


\section{RESEARCH METHOD}

\subsection{CSRD measurement (dependent variable)}

As specified earlier, CSRD, the dependent variable in the model, is a measure of the amount of CSRD made by firms in their annual reports. To measure this CSRD variable, an index was calculated based on each firm's score on a checklist of 21 items pertinent to CSRD information disclosed in the annual report (see Appendix for CSRD items). This checklist of CSRD items is a modified version of a checklist used by Hackston and Milne (1996) and several other CSR studies (e.g., Aras et al., 2010). To measure the value of the CSRD index, the current study followed a procedure similar to that used in prior research (i.e., Muttakin \& Khan, 2014). Specially, for each observation, any item in the CSRD checklist is given the value of 1 if disclosed by the firm in any part of its annual report, and 0 if not. For each firms, the CSRD index is then obtained by determining the ratio of the total score of the disclosed CSRD items recorded for each firm to the maximum possible score, which is 21. Hence, the CSRD index is calculated as follows:

$$
C S R D_{j i n d e x}=\frac{\sum_{t=1}^{n_{j}} x_{i j}}{n_{j}},
$$

where $C S R D_{\text {jindex }}$ - CSRD index for $j$-th firm, $n_{j}$ total possible number of CSRD items for $j$-th firm, $x_{i j}-1$ if the $i$-th item of the CSRD checklist is disclosed by firm $j$, and 0 if not.

\subsection{Independent variables (explanatory variables)}

Prior studies that examine the CSRD-CFP association have typically used one of two types of measures of corporate financial performance: market-based measures or accounting-based measures. Research using market-based measures of firm's financial performance generally examines the linkage between stock market returns and CSRD (e.g., Murray et al., 2006). Research studies using accounting-based measures of financial performance (e.g., Preston \& O'Bannon, 1997; Crisóstomo et al., 2011) have typically used measures that are based on accounting information as proxies of CFP when investigating the CSRDCFP association. While market-based measures of CFP are entirely based on investors' perspective of firm's value, and, therefore, discount the viewpoints of other stakeholder groups (Reverte, 2009), accounting-based measures of CFP are shown to be more stable with respect to their association to CSRD (McGuire et al., 1988). In fact, in a review of 121 empirical CSRD-CFP empirical studies, Wu (2006) demonstrated that accounting-based measures of CFP (i.e., profitability) are better predictors of firm's CSRD than the market-based proxies of financial performance. The current study has adopted accounting-based measures of CFP, consequently, it used firm's return on assets (ROA) as a proxy for CFP similar to related prior studies (e.g., Crisóstomo et al., 2011). The variable ROA is included in the research model to test $\mathrm{H} 1$.

The variable, firm size (SIZE) is included in the research equation to test H2. Similar to most related previous research (e.g., Haniffa \& Cooke, 2005), the natural log of the total assets of the company at the year-end is used as a measure of the company size. The financial leverage of the firm (LEV) variable is included in the regression equation to test H3. It is measured as the firm's total liabilities divided by its total owners' equity. As indicated earlier, empirical findings reported in previous related research about the association between this variable and the amount of CSRD are mixed. Hence, no directional sign is predicted for the LEV variable.

As Table 2 shows, the sampled firms come from 12 industries according to KSE industry-sector classification. To test H4, however, the sampled firms were divided into two main groups according to their potential environmental sensitivity. In particular, the ENVIR dummy variable is added to the research model to represent impact of firm's industry affiliation on the amount of CSRD. This variable takes the value of 1 if the firm is an oil and gas, petrochemicals, or a manufacturing firm, and 0 otherwise.

\subsection{Control variables}

Prior CSRD research (e.g., Cormier et al., 2005) suggested that old firms tend to provide more CSRD than newly established firms. Hence, the 
AGE variable is added to the regression equation to control for the potential impact of firm's age on the amount of CSRD. In addition, prior related research (Walden \& Schwartz, 1997) suggested that CSRD (i.e., environment-related information) may change from one year to another. Therefore, the YEAR dummy variable is included in the regression equation to control for the possible impact of year differences. This variable takes the value of 1 if the firm's annual report is for the year 2012, and 0 if the annual report is for the year 2011.

\subsection{Study sample}

The study sample consists of a total of 114 firm-year observations. The data set pertains to 2011 and/or 2012 annual reports of a randomly selected sample of 81 firms listed in the Kuwait Stock Exchange (KSE). Table 2 shows the number of firms included in the sample, and the different KSE sectors the sampled firms are affiliated to. As shown, the sampled firms represent 12 sectors, including banks (11 firms), financial services (23 firms), insurance (3 firms), real estate (17 firms), oil and gas (3 firms), industrial (9 firms), basic materials ( 2 firms), consumer goods (2 firms), telecommunications (3 firms), healthcare (1 firm), and technology (1 firm). Content analysis was performed on 114 annual reports of firms to extract the data needed for the analysis of interest in current study. In particular, information related to CSRD was hand-collected from the different parts of annual reports, including chairman's statement, directors' report, and supplementary notes. In addition, the financial data needed for the study's analysis were obtained directly from the financial statements' section of the annual reports. The size of the study's sample is fairly reasonable, since the companies included in the study's sample constitute approximately $40 \%$ of companies listed on KSE.

\subsection{Model specification}

A regression model is developed based on prior related research (e.g., Simpson \& Kohers, 2002; Khan et al., 2013) to investigate the study's research hypotheses. In particular, the following OLS regression is used to examine whether the amount of CSRD is related to the various explanatory variables specified in the research hypotheses:

$$
\begin{aligned}
& C S R D=\beta_{0}+\beta_{1} R O A+\beta_{2} S I Z E+\beta_{3} L E V+ \\
& +\beta_{4} E N V I R+\beta_{5} A G E+\beta_{6} Y E A R+\varepsilon,
\end{aligned}
$$

where CSRD - score index of corporate social responsibility disclosure, $R O A$ - the company's net income divided by total assets, SIZE - natural log of the company's total assets, $L E V$ - the company's total liabilities divided by its total equity, ENVIR - dummy variable taking a value of 1 if the company belongs to oil and gas, petrochemicals, or industrial sector, and 0 otherwise, $A G E$

\begin{tabular}{|c|c|c|}
\hline \multicolumn{3}{|c|}{ Panel A. The sampled firms' distribution across sectors } \\
\hline Sector & No. of firms in sector & Of sample, \% \\
\hline Financial services & 23 & 28.4 \\
\hline Real estate & 17 & 21 \\
\hline Banks & 11 & 13.6 \\
\hline Industrial & 9 & 11.1 \\
\hline Consumer services & 6 & 7.4 \\
\hline Insurance & 3 & 3.7 \\
\hline Oil and gas & 3 & 3.7 \\
\hline Telecommunication & 3 & 3.7 \\
\hline Basic materials & 2 & 2.5 \\
\hline Consumer goods & 2 & 2.5 \\
\hline Healthcare & 1 & 1.2 \\
\hline Technology & 1 & 1.2 \\
\hline Total & 81 & 100 \\
\hline \multicolumn{3}{|c|}{ Panel B. Observations by fiscal year of annual report } \\
\hline From 2011 annual reports & 48 & 42 \\
\hline From 2012 annual reports & 66 & 56 \\
\hline Total & 114 & 100 \\
\hline
\end{tabular}

Table 2. Characteristics of the study sample 
- the number of years since the firm's founding, $Y E A R$ - one if the annual report is for 2012 fiscal year, and zero if it is for 2011, $\varepsilon$ - error term.

Numerous measures have been used to proxy for CFP. Return on Assets, ROA, however, was one of the most used measures of firm's CFP in previous related research (e.g., Berman et al., 1999; Simpson \& Kohers, 2002). According to Jensen and Meckling (1976), corporate agency-related costs increase when the size of the firm increases. Therefore, larger firms are more likely to disclose more information related to their operation and activities than smaller firms. Previous accounting and CSR research (e.g., Murali \& Welch, 1989) has used several measures to proxy for firm size. Much of this research, however, have used firm's total assets as a surrogate of firm size. The current study uses total assets as a measure of firm size, and the SIZE variable is, therefore, included in the research model. According to several studies (e.g., Bellaoui \& Karpik), the amounts of CSR disclosure is negatively related to firm's financial leverage. The LEV variable is, therefore, added to the equation as a proxy for firm's financial leverage. Previous research (e.g., Sethi, 1976) posits that CSR disclosure is more likely for oil and energy producing firms. As Sethi (1976) suggests, these firms use CSR disclosures as "advocacy advertising". Accordingly, the ENVIR dummy variable is added to the equation as a surrogate for firm's affiliation to the oil and energy industry.

\section{RESULTS AND DISCUSSION}

\subsection{Descriptive statistics}

Descriptive statistics are shown in Table 3. As this table shows, firms comprising the study's sample vary from rather small firms, with total assets of KD 5,851,063, to considerably large firms, with total assets of about KD16,424,487,000. Table 3 reveals that the average CSRD score for firms included in the sample is about 0.19 . This means that, on average, each firm disclosed about 4 of the 21 CSRD checklist items in its annual report. Table 3 shows that the average ROA for the sampled firms is about $3.8 \%$, while the average leverage ratio is about 2.13. Table 3 also shows that the average age of the sampled firms is around 30 years, and that about $18 \%$ of firms included in the sample were from "environmentally sensitive" industries (e.g., oil, petrochemicals, and industrial firms). As shown in Table 3, about $58 \%$ of the study's observations pertain to 2012 annual reports, while about $42 \%$ of the observations are related to 2011 annual reports.

\subsection{Univariate analysis}

Pearson correlations for the variables included in the regression equation are shown in Table 4. As Table 4 demonstrates, CSRD score is positively and significantly correlated with firm size ( $p$-val-

Table 3. Descriptive statistics

\begin{tabular}{|c|c|c|c|c|c|}
\hline Variable & $\mathbf{N}$ & Min. & Max. & Mean & S.D. \\
\hline \multicolumn{6}{|c|}{ The dependent variable } \\
\hline CSRD & 114 & .00 & .86 & .19 & .18 \\
\hline \multicolumn{6}{|c|}{ Independent variables } \\
\hline SIZE (total assets) (KD) & 114 & $5,851,063$ & $16,424,487,000$ & $1,090,297,029$ & $2,646,187,907$ \\
\hline ROA & 114 & .00 & .28 & .038 & .048 \\
\hline LEV & 114 & .00 & 10.123 & 2.13 & 2.42 \\
\hline AGE & 114 & 9 & 62 & 29.43 & 14.88 \\
\hline Variable & Value & Frequency & $\%$ & - & - \\
\hline \multirow{2}{*}{ ENVIR } & 0 & 94 & 82 & - & - \\
\hline & 1 & 20 & 18 & - & - \\
\hline \multirow{2}{*}{ YEAR } & 0 & 48 & 42 & - & - \\
\hline & 1 & 66 & 58 & - & - \\
\hline
\end{tabular}

Note: CSRD (corporate social responsibility disclosure score index), ROA (return on asset), SIZE (firm size), LEV (firm's financial leverage), ENVIR (firm's industry affiliation), AGE (firm age), YEAR (2011 or 2012). 
Table 4. Correlation matrix of variables

\begin{tabular}{|c|c|c|c|c|c|c|c|}
\hline Variable & CSRD & ROA & SIZE & LEV & ENVIR & AGE & YEAR \\
\hline CSRD & 1.000 & - & - & - & - & - & - \\
\hline ROA & $.168^{*}$ & 1.000 & - & - & - & - & - \\
\hline SIZE & $.260 * * *$ & $-.222^{* *}$ & 1.000 & - & - & - & - \\
\hline LEV & $.159^{*}$ & $-.273^{* * *}$ & $.633^{* *}$ & 1.000 & - & - & - \\
\hline ENVIR & .088 & $.274^{* * *}$ & -.101 & -.133 & 1.000 & - & - \\
\hline AGE & $.180^{*}$ & -.097 & $.283^{* * *}$ & $.281^{* * *}$ & -.035 & 1.000 & - \\
\hline YEAR & -.052 & -.037 & -.009 & -.020 & -.074 & -.123 & 1.000 \\
\hline
\end{tabular}

Note: CSRD (corporate social responsibility disclosure score index), ROA (return on asset), SIZE (firm size), LEV (firm's financial leverage), ENVIR (firm's industry affiliation), AGE (firm age). YEAR (2011 or 2012). * **, and ${ }^{* * *}$ denote the 2-tailed significance at the $0.10,0.05$, and 0.01 levels, respectively.

ue $=0.005)$, firm's ROA ( $p$-value $=0.074)$, firm's financial leverage ( $p$-value $=0.09$ ), and firm's age $(p$-value $=0.10)$. As this table shows, except for the correlation between the SIZE and LEV variables (0.633), correlations among the variables are quite low, with the highest below 0.30 . Yet, to further investigate the possibility of multicollinearity among explanatory variables, the Variance Inflation Factors (VIF) are calculated for each variable, and results are reported in Table 4. As the results show, the greatest VIF value reported is 1.755 , which is lower than the VIF critical value of 10 (Neter et al., 1983). Hence, multicollinearity should not be a concern here.

\subsection{The multivariate analysis}

As indicated earlier, the current study aims at examining whether the amount of CSRD made by firms listed on KSE is significantly related to CFP (H1), firm size (H2), firm's financial leverage (H3), and/or firm's industry affiliation (H4). To investigate these research hypotheses, a regression model including variables used as proxies of the test variables of interest, in addition to some control variables, is used. The regression results are shown in Table 5. The model equation is as follows:

$$
\begin{aligned}
& C S R D=\beta_{0}+\beta_{1} R O A+\beta_{2} S I Z E+\beta_{3} L E V+ \\
& +\beta_{4} E N V I R+\beta_{5} A G E+\beta_{6} Y E A R+\varepsilon .
\end{aligned}
$$

As Table 5 shows, the $R$-square of the regression model is 0.140 , and the $F$-statistics is 2.892 ( $p$-value $=0.012$. The regression results show that the CSRD score is positively and significantly related to firm's ROA ( $p$-value $=0.019$ ), as well as firm's size $(p$-value $=0.026)$, which provide support to $\mathrm{H} 1$ and $\mathrm{H} 2$. In particular, these empirical re-

\begin{tabular}{|c|c|c|c|c|c|}
\hline Variables & Predicted sign & Estimated coefficient & SE & $P$-value & VIF \\
\hline Constant & & -3.95 & 0.216 & .070 & \\
\hline $\mathrm{ROA}$ & + & 0.839 & 0.353 & $.019 * *$ & 1.158 \\
\hline SIZE & + & 0.061 & 0.027 & $.026^{* *}$ & 1.709 \\
\hline LEV & $?$ & 0.002 & 0.009 & 0.809 & 1.755 \\
\hline ENVIR & + & 0.043 & 0.058 & 0.535 & 1.091 \\
\hline AGE & + & 0.001 & 0.001 & 0.214 & 1.125 \\
\hline YEAR & $?$ & -0.008 & 0.032 & 0.809 & 1.023 \\
\hline$R$-square & \multicolumn{5}{|c|}{0.140} \\
\hline F-statistics & \multicolumn{5}{|c|}{2.892} \\
\hline$P$-value $(F$-statistics $)$ & \multicolumn{5}{|c|}{0.012} \\
\hline
\end{tabular}

Table 5. Regression results

Note: CSRD (corporate social responsibility disclosure score index), ROA (return on asset), SIZE (firm size), LEV (firm's financial leverage), ENVIR (firm's industry affiliation), AGE (firm age), YEAR (2011 or 2012). ${ }^{*}{ }^{* *}$, and ${ }^{* * *}$ denote the 2 -tailed significance at the $0.10,0.05$, and 0.01 levels, respectively. 
sults show evidence of a significant and positive association between the amount of CSRD made by firms listed on KSE and their financial performance. Moreover, the results in Table 5 show that the amount of CSRD made by firms listed on KSE is significantly and positively related to firm size. This result means that, in general, larger firms listed on KSE tend to provide more CSRD than smaller firms. The reported regression results also show that the regression coefficient of the LEV variable is insignificant ( $p$-value $=0.809)$. Hence, the regresh sion results do not provide support for $\mathrm{H} 3$. The results in Table 5 also indicate that the coefficient of the ENVIR variable is positive as expected but is statistically insignificant ( $p$-value $=0.353$ ), which does not provide support for $\mathrm{H} 4$. The regression results in Table 5 also reveal that the regression coefficients of the AGE and YEAR control variables are statistically insignificant, showing $p$-values of 0.214 and 0.809 , respectively.

\section{SUMMARY AND CONCLUSIONS}

This study employs data from the Kuwaiti emerging market to investigate of the association between the amount of CSRD and a number of firm characteristics. In particular, this study aims at providing empirical evidence about factors influential in determining the amount of CSRD made by Kuwaiti firms. Consistent with to findings documented in several prior CSRD studies conducted in different markets (e.g., Bani-Khalid et al., 2017; Muttakin et al., 2015; Alturki, 2014), the results reported in this study reveal a significant association between the amount of CSRD made by Kuwaiti firms and CFP. This indicates that firms with more CSRD are generally firms that are doing well financially. Moreover, the current study's results report a significant association between the amount of CSRD and firm size. This result is similar to findings reported in other related studies (e.g., Bani-Khalid et al., 2017; Alturki, 2014; Macarulla \& Talalweh, 2012), and indicates that larger firms, which are expected to be more vulnerable to public scrutiny, tend to disclose greater amounts of CSRD than smaller firms. The results, however, show that the amount of CSRD is not statistically related to firm's leverage nor firm's industry affiliation. Such results are not surprising, though, as similar results are reported in several prior CSRD studies (e.g., Alturki, 2014). The substantiated empirical findings offered by the current study about the association between the amount of CSRD and certain corporate characteristics is expected to be useful to both investors and firm's management in understanding how CSRD are related to these firm characteristics. The results reported by the current study can also be useful to regulator and policy makers in the development of regulations related to CSRD practices by firms in Kuwait.

This study is subject to some worthy of noting limitations. For example, the current study's examination of the amount of CSRD is limited to information disclosed in firms' annual reports, and hence does not include disclosures made though other media and news channels, such as newspapers and television. Therefore, future similar research can be designed to include these other media and news channels in the analysis of the amount of CSRD. Another limitation of the current study is that its examination of CSRD is restricted to only firms listed on KSE. Future research, therefore, can be conducted to examine CSRD made by other kinds of firms in the Kuwaiti market. The check-list used to measure the amount of CSRD used in the current study is a modified version of checklists designed by researchers examining CSRD in markets with settings that may be different than that of the Kuwaiti market, and, hence, may not have appropriately captured CSRD made by the Kuwaiti firms. It seems, therefore, important for future research to pay more attention to the use of CSRD checklists that are appropriate to the market settings where the research examination is being conducted. Moreover, other new variables can be tested in the current study such as corporate governance mechanisms. Another valuable avenue for future research is to replicate this kind of investigation using larger and more recent data sets and different research approaches. 


\section{REFERENCES}

1. Al-Faraih, M., Al-Anezi, F., \& Almujamed, H. (2012). The Influence of Institutional and Government Ownership on Firm Performance: Evidence From Kuwait. International Business Research, 5(10), 192-200. http:// dx.doi.org/10.5539/ibr.v5n10p192

2. Alturki, K. (2014). Voluntary Disclosure by Saudi Companies. Research Journal of Finance and Accounting, 5(20), 77-94. Retrieved from https://www.iiste.org/Journals/ index.php/RJFA/article/view/16924

3. Aras, G., Aybars, A., \& Kutlu, O. (2010). Managing Corporate Performance: Investigating the Association between Corporate Social Responsibility and Financial Performance in Emerging Markets. International Journal of Productivity and Management, 59(3), 229-254. https://doi. org/10.1108/17410401011023573

4. Bani-Khalid, T., Kouhy, R., \& Hassan, A. (2017). The Impact of Corporate Characteristics on Social and Environmental Disclosure (CSED): The Case of Jordan. Journal of Accounting and Auditing: Research \& Practice. https://doi. org/10.5171/2017.369352

5. Belkaoui, A., \& Karpik, P. (1989). Determinants of the Corporate Decision to Disclose Social Information. Accounting, Auditing \& Accountability Journal, 2(1), 36-51. https://doi. org/10.1108/09513578910132240

6. Berman, S., Wicks, A., Kotha, S., \& Jones, T. (1999). Does Stakeholder Orientation Matter? The Relationship between Stakeholder Management Models and Firm Financial Performance. Academy of Management Journal, 42(5), 488-506. https://doi.org/10.5465/256972

7. Bowman, E., \& Haire, M. (1976). Social Impact Disclosure and Corporate Annual Reports. Accounting, Organizations, and Society, 1(1), 11-21. https://doi. org/10.1016/0361-3682(76)90004-0

8. Bujaki, M., Richardson, A. (1997). A Citation Trail Review of the Uses of Firm Size in Accounting Research.
Journal of Accounting Literature, 16, 1-27.

9. Carroll, A. (2000). A Commentary and an Overview of Key Questions on Corporate Social Performance Measurement. Business and Society, 39, 466-478. https://doi. org/10.1177/000765030003900406

10. Chang, Y., Chen, T., \& Shu, M. (2018). Corporate Social Responsibility, Corporate Performance, and Pay-Performance Sensitivity - Evidence from Shanghai Stock Exchange Social Responsibility Index. Emerging Markets Finance and Trade, 54(5), 1183-1203. https://doi.org/10.1080/1 540496X.2016.1273768

11. Clarke, J., \& Gibson-Sweet, M. (1999). The Use of Corporate Social Disclosures in the Management of Reputation and Legitimacy: A Cross Sectoral Analysis of UK Top 100 Companies. Business Ethics: A European Review, 8(1), 5-13. https:// doi.org/10.1111/1467-8608.00120

12. Cormier, D., Magnan, M., \& Van Velthoven, B. (2005). Environmental Disclosure Quality in Large German Companies: Economic Incentives, Public Pressures or Institutional Conditions? European Accounting Review, 14(1), 3-39. https://doi.org/10.1080/0963818042000339617

13. Cowen, S., Ferreri, L., \& Parker, L. (1987). The Impact of Corporate Characteristics on Social Responsibility Disclosure: a Typology and Frequency-based Analysis. Accounting, Organizations and Society, 12(2), 111-122. https://doi.org/10.1016/03613682(87)90001-8

14. Crisóstomo, V., de Souza Freire, F., \& de Vasconcellos, F. (2011). Corporate Social Responsibility, Firm Value and Financial Performance in Brazil. Social Responsibility Journal, 7(2), 295-309. https://doi. org/10.1108/17471111111141549

15. Dhaliwal, D., Li, O., Tsang, A., \& Yang, Y. (2011). Voluntary Nonfinancial Disclosure and Cost of Equity Capital: The Initiation of Corporate Social Responsibility
Reporting. The Accounting

Review, 86(1), 59-100. https://doi. org/10.2308/accr.00000005

16. Dye, R., \& Sridhar, S. (1995). Industry-Wide Disclosure Dynamics. Journal of Accounting Research, 33(1), 157-174. https://doi. org/10.2307/2491297

17. Elias, N., \& Epstein, M. (1975). Dimension of Corporate Social Reporting. Management Accounting, 56(9), 36-40

18. Elsbach, K., \& Sutton, R. (1992). Acquiring Organizational Legitimacy through Illegitimate Actions: A Marriage of Institutional and Impression Management Theories. Academy of Management Journal, 35(4), 699-738. Retrieved from https://www.gsb.stanford.edu/ faculty-research/publications/acquiring-organizational-legitimacythrough-illegitimate-actions

19. Freeman, R. (1999). Divergent Stakeholder Theory. Academy of Management Review, 24(2), 233-236. https://doi.org/10.2307/259078

20. Freeman, R., \& Philips, R. (2002). Stakeholder Theory: A Libertarian Defence. Business Ethics Quarterly, 12(3), 331-349. https://doi. org/10.2307/3858020

21. Gray, R. (2006). Does Sustainability Reporting Improve Corporate Behavior? Wrong Question? Right Time? Accounting and Business Research, 36, 65-88. https://doi.org/1 0.1080/00014788.2006.9730048

22. Gray, R., Owen, D., \& Adams, C. (1996). Accounting and Accountability. London- Prentice Halls Inc. Retrieved from https://lib. ugent.be/catalog/rug01:000407455

23. Hackston, D., \& Milne, M. (1996). Some Determinants of Social and Environmental Disclosures in New Zealand Companies. Accounting, Auditing \& Accountability Journal, 9(1), 77-108. https://doi. org/10.1108/09513579610109987

24. Haniffa, R., \& Cooke, T. (2005). The Impact of Culture and Governance on Corporate Social Reporting. Journal of Accounting and Public Policy, 24(5), 391-430. https://doi.org/10.1016/j.jaccpubpol.2005.06.001 
25. Khan, A., Muttakin, M., \& Siddiqui, J. (2013). Corporate Governance and Corporate Social Responsibility Disclosures: Evidence from an Emerging Economy. Journal of Business Ethics, 114(2), 207-223. https://doi.org/10.1007/s10551-0121336-0

26. Khlif, H., \& Souissi, M. (2010). The Determinants of Corporate Disclosure: A Meta-analysis. International Journal of Accounting and Information Management 18(3), 198-219. https://doi. org/10.1108/18347641011068965

27. Kok, P., Wiele, T., McKenna, R., \& Brown, A. (2001). A Corporate Social Responsibility Audit Within A Quality Management Frame Work. Journal of Business Ethics, 31(4), 285-297. https://doi. org/10.1023/A:1010767001610

28. Kokubu, K., Tornimasu, K., \& Yarnagarni, T. (1994). Green Reporting in Japan: Accountability and Legitimacy, Dundee Discussion Papers in Accountancy and Business Finance. Centre for Social and Environmental Accounting Research, University of Dundee.

29. Kotonen, U. (2009). Formal Corporate Social Responsibility Reporting in Finish Listed Companies. Journal of Applied Accounting Research, 10(3), 176-207. https://doi. org/10.1108/09675420911006406

30. Maignan, I., \& Ferrell, O. (2004). Corporate Social Responsibility and Marketing: An Integrative Framework. Journal of the Academy of Marketing Science. https://doi. org/10.1177/0092070303258971

31. McGuire, J., Sundgren, A., \& Schneeweis, T. (1988). Corporate Social Responsibility and Firm Financial Performance. Academy of Management, 31(4), 854-872. https://doi.org/10.5465/256342

32. Milne, M. (2002). Positive Accounting Theory, Political Costs and Social Disclosure Analysis: A Critical Look. Critical Perspectives on Accounting, 13, 369-395. https:// doi.org/10.1006/cpac.2001.0509

33. Mousa, G. (2010). Stakeholder Theory as an Arch to Manage Successful Legitimacy Strategies. Int. J. Critical Accounting, 2(4)
399-418. https://doi.org/10.1504/ IJCA.2010.036178

34. Murali, R., \& Welch, J. (1989). Agents Owners, Control and Performance. Journal of Business Finance and Accounting, 16(3), 385-398. https://doi. org/10.1111/j.1468-5957.1989. tb00025.x

35. Murray, A., Sinclair, D., Powel, D., \& Gray, R. (2006). Do Financial Markets Care About Social and Environmental Disclosure? Further Evidence and Exploration from the UK. Accounting, Auditing \& Accountability Journal, 19(2), 228-55. https://doi. org/10.1108/09513570610656105

36. Muttakin, M., \& Khan, A. (2014). Determinants of Corporate Social Disclosure: Empirical Evidence From Bangladesh. Advances in Accounting, 30(1), 168-175. https:// doi.org/10.1016/j.adiac.2014.03.005

37. Muttakin, M., Khan, A., \& Subramaniam, N. (2015). Firm Characteristics, Board Diversity and Corporate Social Responsibility: Evidence from Bangladesh. Pacific Accounting Review, 27(3), 353-372. https://doi.org/10.1108/PAR-012013-0007

38. Neter, J., Wasserman, W., \& Kutner, M. (1983). Applied Linear Regression Models. Homewood, Irwin, Illinois.

39. Peloza, J., \& Papania, L. (2008). The Missing Link between Corporate Social Responsibility and Financial Performance: Stakeholder Salience and Identification. Corporate Reputation Review, 11(2), 169-181. https://doi.org/10.1057/crr.2008.13

40. Preston, L., \& O’Bannon, D. (1997). The Corporate Social-Financial Performance Association: A Typology and Analysis. Business and Society, 36, 419-429. https://doi. org/10.1177/000765039703600406

41. Purushothaman, M., Tower, G., Hancock, R., \& Taplin, R. (2000). Determinants of Corporate Social Reporting Practices of Listed Singapore Companies. Pacific Accounting Review, 12(2), 101-133.

42. Reverte, C. (2009). Determinants of Corporate Social Responsibility Disclosure Ratings by Spanish Listed Companies. Journal of
Business Ethics, 88(2), 351-366. https://doi.org/10.1007/s10551-0089968-9

43. Salzmann, O., Somers, A., \& Steger, U. (2005). The Business Case for Corporate Sustainability: Literature Review and Research Options. European Management Journal, 23(1), 27-36. https://doi. org/10.1016/j.emj.2004.12.007

44. Sethi, S. (1976). Issue-Oriented Corporate Advertising: Tax Treatment of Expenditures. California Management Review, 19(1), 5-13. https://doi. org/10.2307/41164677

45. Simpson, W., \& Kohers, T. (2002)

The Link between Corporate Social and Financial Performance: Evidence from the Banking Industry. Journal of Business Ethics, 35(2), 97-109. https://doi. org/10.1023/A:1013082525900

46. Singhvi, S., \& Desai, H. (1971). An Empirical Analysis of the Quality of Corporate Financial Disclosure. The Accounting Review, 46(1), 129-138. Retrieved from http://www.jstor. org/stable/243894

47. Solomon, J. (2010). Corporate Governance and Accountability (3rd ed.). Chichester: Wiley. Retrieved from https://trove.nla.gov.au/version/35671780

48. Walden, W., \& Schwartz, B. (1997). Environmental Disclosures and Public Policy Pressure. Journal of Accounting and Public Policy, 16, 125-54. https://doi.org/10.1016/ S0278-4254(96)00015-4

49. Wallace, R., Naser, K., \& Mora, A (1994). The Association between the Comprehensiveness of Companies Annual Reports and Firms Characteristics in Spain. Accounting and Business Research, 25(97), 41-53.

50. Wu, M. (2006). Corporate Social Performance, Corporate Financial Performance, and Firm Size: A Meta-Analysis. Journal of American Academy of Business, 8(1), 163-171. 


\section{APPENDIX}

\section{CSRD ITEMS}

\section{Environment}

- That the company's operations are in compliance with pollution laws and regulations.

- That pollution from operations has been or will be reduced.

- Conservation of natural resources (for example, recycling materials).

- Receiving an award relating to the company's environmental policies.

\section{Employee health and safety}

- Disclosing employee's accident statistics.

- Complying with safety standards in the work environment.

- Receiving a safety award.

- Providing health care for employees.

- Sponsoring employee training.

- Providing assistance for employees who have been made redundant.

- Providing staff accommodation/staff home ownership schemes.

- Providing information about the amount/policies of employees' compensation.

- Providing statistics on the number of staff, the length of service in the company.

\section{Products}

- Information on the safety of the firm's product.

- Receiving any award related to the quality of the firm's products (for example: ISO 9000).

- Information about the company's efforts to improve its product.

- Information about the company's customer services.

\section{Community involvement}

- Donations to support any community activities and events.

- Charity programs.

- Enabling summer or part-time employment of students.

- Sponsoring health projects for the community. 